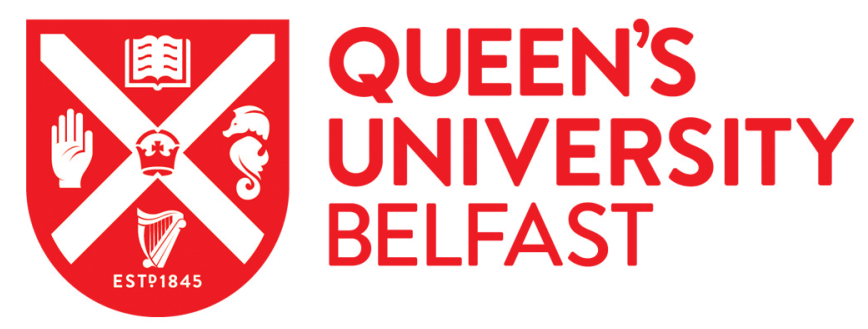

\title{
Anatomising Irish Rebellion: the Cromwellian Delinquency Commissions, the Books of Discrimination and the 1641 Depositions
}

Cunningham, J. (2016). Anatomising Irish Rebellion: the Cromwellian Delinquency Commissions, the Books of Discrimination and the 1641 Depositions. Irish Historical Studies, 40(157), 22-42.

https://doi.org/10.1017/ihs.2016.3

Published in:

Irish Historical Studies

Document Version:

Peer reviewed version

Queen's University Belfast - Research Portal:

Link to publication record in Queen's University Belfast Research Portal

Publisher rights

(C) 2016 Irish Historical Studies Publications Ltd.

This work is made available online in accordance with the publisher's policies. Please refer to any applicable terms of use of the publisher.

\section{General rights}

Copyright for the publications made accessible via the Queen's University Belfast Research Portal is retained by the author(s) and / or other copyright owners and it is a condition of accessing these publications that users recognise and abide by the legal requirements associated with these rights.

Take down policy

The Research Portal is Queen's institutional repository that provides access to Queen's research output. Every effort has been made to ensure that content in the Research Portal does not infringe any person's rights, or applicable UK laws. If you discover content in the Research Portal that you believe breaches copyright or violates any law, please contact openaccess@qub.ac.uk. 
Anatomising Irish rebellion: the Cromwellian delinquency commissions, the books of discrimination and the 1641 depositions

In the early 1650s the ability of the Cromwellian government in Ireland to implement many of its preferred policies was severely threatened by an acute information deficit relating to the 1641 rebellion and its aftermath. As is well known, many witness testimonies had been collected from Protestant refugees and others in the 1640s. Those documents, now part of the archive known as the 1641 depositions, had helped to inform pamphlets that depicted the rebellion as an attempted general massacre of Protestants in which huge numbers had perished. ${ }^{1}$ Yet the actual punishment of murders required the distillation of a supposed general massacre into particular acts perpetrated by identifiable persons. From mid-1652 Dr Henry Jones duly spearheaded a campaign to gather fresh evidence to support the work of a purposely-erected High Court of Justice. A large number of the witness examinations generated by this process also survive among the 1641 depositions. ${ }^{2}$

The implementation of the land settlement necessitated the translation, on a still greater scale, of the general into the particular. From the point of view of the English parliament, an enormous redistribution of Catholic land was seen as necessary to secure Ireland and to pay off army arrears and other debts. The execution of these policies required that the broad sweep of parliamentary legislation be channelled into an administrative framework that could process the claims of tens of thousands of individuals. ${ }^{3}$ The task of clarifying the landed entitlements of existing Catholic proprietors was particularly complex. In England in the 1640s, royalist and Catholic estates had been sequestered and 
composition fines were subsequently levied on a sliding scale in accordance with the adjudged degree of each landowner's 'delinquency'.4 The Act for the Settling of Ireland passed at Westminster in 1652 echoed some elements of this approach. Those Catholics innocent of major involvement in the Irish rebellion, but who nonetheless fell short of 'constant good affection' to the 'English interest', were made entitled to lands equivalent to either one-third or twothirds of their estates. Separately, the various articles of surrender agreed in 1652 guaranteed that many of those who had been deeply complicit in the Catholic war effort would retain some land. A further layer of complexity was added with the announcement in mid-1653 of a decision to satisfy Catholic land claims by means of a scheme of transplantation to Connacht. ${ }^{5}$

The legislative benchmarks set down for measuring an individual Catholic's land entitlements included involvement in the first year of the rebellion and the holding of office under the Catholic Confederation that had controlled much of the country in the $1640 \mathrm{~s} .{ }^{6}$ In assessing the guilt of royalists in England, the parliament could harness the knowledge possessed by county committees, local officials and supporters. By contrast, in the early 1650s the roots of the English regime in Ireland were both new and shallow. Buttressed by sword and musket, it saw reason to despise the Catholics, to detest the Protestant royalists and to distrust almost everybody else. ${ }^{7}$ The task of retrospectively assembling the detailed information needed to adjudicate Catholic land claims was thus a daunting one. For most of the country, the government was without a network of trusted collaborators possessed of long local experience. It also lacked ready access to requisite large bodies of relevant information. The records of the Catholic Confederation could be expected to 
reveal a great deal, but in 1653 their whereabouts remained unknown. ${ }^{8}$ The depositions collected in the early 1640s and later again for the High Court of Justice were, whatever their other strengths and shortcomings, simply not systematic enough for the task at hand. In an effort to address its information requirements, the government elected to pursue a further round of evidence gathering by means of delinquency commissions. ${ }^{9}$ This article is concerned with the course and outcomes of this effort, and particularly with the substantial body of relevant evidence that has survived among the 1641 depositions.

While the 1641 depositions are undoubtedly the best known and most controversial historical source for early modern Ireland, the distinct nature of some 1,260 items among that collection has gone largely unnoticed. ${ }^{10}$ These were created in 1653-4 by the Cromwellian delinquency commissions and can accordingly be labelled as 'delinquency depositions'. In successive categorisations of the depositions as a whole, the delinquency depositions have routinely been identified as part of the evidence gathered for the High Court of Justice. ${ }^{11}$ Those scholars who have utilised this part of the collection have either treated them as such, or used them without seeking to explain their different character. ${ }^{12}$ At the same time, historians of the Cromwellian land settlement have made little more than a passing mention of the delinquency proceedings. ${ }^{13}$ The recent digitisation of the 1641 depositions has, however, opened up a range of new research possibilities. This article will contextualise and examine the role played by the delinquency commissions in enabling the implementation of both the Cromwellian and Restoration land settlements, drawing attention to overlooked and underexplored aspects of those key episodes. It will also discuss some parts of the remarkably rich material preserved in the delinquency 
depositions from Co. Wexford. ${ }^{14}$ This analysis will enable important new insights into the origins and contents of a large section of the 1641 depositions, as well as into the administrative and legal frameworks surrounding the mid-seventeenth century revolution in Irish landownership.

In November 1653 the Dublin government appointed teams of 'commissioners for examining the delinquency of Irish and other proprietors' in each of the fifteen precincts into which the country was then divided. ${ }^{15}$ They were tasked with establishing the precise nature of each landowner's involvement in the decade of upheaval that followed the outbreak of the 1641 rebellion. Because they allowed the authorities to discriminate the guilt or innocence of suspected delinquents, the resulting documents, together with the other depositions collected since 1641 , soon came to be identified collectively as the 'books of discrimination'.16 Unfortunately, the archive now known as the 1641 depositions represents only a part of the original books of discrimination. The delinquency documents surviving among the 1641 depositions are drawn almost entirely from two counties. ${ }^{17}$ Other evidence indicates that they once existed for at least ten counties, and it is possible that such documents were also compiled in additional regions of the country. ${ }^{18} \mathrm{~A}$ volume relating to the precinct of Athlone, which was destroyed in a fire in the Public Record Office of Ireland in 1922, contained depositions detailing the conduct of 363 proprietors. ${ }^{19}$ As multiple testimonies were usually collected about each individual under investigation, it is likely that this lost Athlone volume contained more than 700 depositions. A 1663 reference to the lost delinquency depositions from Co. Kerry indicates that 
they occupied at least 455 folios. ${ }^{20}$ It is accordingly reasonable to conclude that the greater part of that class of records has not survived.

The Athlone volume of depositions lost in 1922 was part of the so-called 'Commonwealth Records', a substantial archive of the Cromwellian government papers. ${ }^{21}$ The many other delinquency depositions that have not survived were most likely destroyed in the accidental fire that consumed the Council Chamber and the Surveyor General's Office in Dublin on 15 April $1711 .^{22}$ Fortunately, the clerk of the Irish Privy Council, Matthew Barry, had taken part of the books of discrimination into his private possession at some point after $1670 .{ }^{23}$ Barry's motives are unknown, but he may have feared for the safety of the depositions under Jacobite rule. Such fears would have been justified, as in 1689 a Catholicdominated Irish parliament ordered the destruction of 'all or any the books of crimination and examinations relating thereunto'.24 Barry's collection of 1641 depositions subsequently passed into other hands, eventually reaching the library of Trinity College Dublin in $1741 .^{25}$

Of the approximately 1,260 delinquency depositions preserved among the 1641 depositions, all bar two were recorded in the Cromwellian precincts of Cork and Wexford. ${ }^{26}$ There are 513 extant documents from Wexford, constituting over eighty per cent of the items in the two volumes of 1641 depositions for that county. These depositions are arranged as case files, with multiple documents about each individual suspect usually being grouped together. They are, with many inconsistencies, further clustered alphabetically by surname, but these clusters are not in turn ordered in alphabetical sequence. ${ }^{27}$ The archival picture for the precinct of Cork, which encompassed part of Co. Waterford, is even more jumbled. Most notably, a considerable 
number of residents of the precinct gave evidence concerning persons from other counties. For example, a cluster of forty-three depositions originating in Cork but concerning suspected delinquents in counties Clare and Limerick was ultimately bound in the joint volume of depositions for those latter two counties. ${ }^{28}$ The evidence from Cork certainly measures up to William O'Sullivan's characterisation of the 1641 depositions as an 'archival quagmire'. ${ }^{29}$ Altogether, nearly 750 delinquency depositions recorded in the precinct of Cork have survived. ${ }^{30}$ The fact that almost eighty of these were sworn by deponents who would appear to have been resident elsewhere in the country in 1641 hints at the dislocation resulting from a decade of conflict.

The delinquency commissioners initially appointed by the Dublin government in 1653 totalled 151 individuals; more were added locally over the following months. The largest team, of nineteen, was named in the precinct of Belfast, while just five were appointed in Waterford. In each precinct the first person named for appointment was the local military governor. ${ }^{31}$ These men were mostly Cromwellian newcomers and they shouldered wide-ranging responsibilities within their respective regions; indeed they were arguably already overworked. Fortunately for these men, the government did not demand their direct involvement in the collection of evidence. The relevant instructions issued from Dublin authorised the commissioners to 'choose out one amongst yourselves who is most fitted and best at leisure to undertake the special management of this affair'. ${ }^{32}$ This advice was followed in Cork, where 
Lieutenant-Colonel Francis Wheeler appears to have enjoyed particular responsibility for collecting depositions. ${ }^{33}$

In Wexford thirteen men were named in the original commission. Fifteen commissioners ultimately shared the workload, carrying out their duties in teams of two or three. ${ }^{34}$ These men were already active in a range of military and civil roles in the local government, which was headed by Colonel Thomas Sadleir. The Hertfordshire-born Sadleir crossed to Ireland with Cromwell in 1649 as adjutant-general of foot. By 1652 he was in charge of a foot regiment comprised of companies formerly commanded by Colonels Isaac Ewer and George Cooke, both of whom had been killed in fighting. ${ }^{35}$ Sadleir's officers provided the backbone of his administration in the precinct. Those active as delinquency commissioners included Lieutenant-Colonel John Puckle, Major John Overstreet, Captain Thomas Dancer, Captain William Moore, Captain William Woodward and Major John Walker. Of the other commissioners, Thomas Harte, Matthew Stoddard and Edward Tomlin were also army captains, while Edward Withers was a master-gunner. ${ }^{36}$ Richard Neale was presumably from a local family; his namesake Constantine was a Wexford merchant, while in 1654 the sixty-year old Morris Neale of New Ross provided evidence of the delinquency of a number of the town's inhabitants. ${ }^{37}$ Ambrose Andrews had been a revenue commissioner in Kilkenny Precinct in 1651. Subsequently his colleagues as revenue commissioners in Wexford included Bartholomew Hussey and Thomas Dowse, both of whom were also delinquency commissioners. ${ }^{38}$ Many of these men continued to act in a variety of roles throughout the decade. For example, when the commission of the peace was revived in the county in 1655 , eight of the delinquency commissioners were among those appointed as justices. ${ }^{39}$ Some 
were also major beneficiaries of the land settlement. Most notable was Colonel Sadleir, who secured almost 5,000 acres in north Co. Tipperary and more than 2,000 acres in Co. Galway. ${ }^{40}$

While Sadleir was a prominent figure in 1650s Ireland, his role as a delinquency commissioner appears to have been minimal. His signature appeared on just one deposition, which concerned the conduct of Nicholas Stafford of Ballymacane. ${ }^{41}$ Sadleir's interest in Stafford was probably due to his key local role in 1641. As part of its efforts to prevent the spread of disorder from Ulster, the Dublin government had appointed Catholic governors in a number of counties, with Stafford filling this post in Wexford. He had gone about raising two regiments to keep the peace, but these forces instead promptly joined the rebellion, apparently without Stafford's consent. Shortly thereafter he threw in his lot with the rebels, but not before exploring how he might free himself from his obligation to the government by procuring a writ of supersedeas from Dublin. ${ }^{42}$ As Stafford was essentially one of Sadlier's predecessors as governor of the county, the colonel's concern with this case in particular is unsurprising. Another senior officer, Lieutenant-Colonel Puckle, also played only a minor role as a commissioner. He signed just two depositions relating to inhabitants of New Ross, the town of which he was governor. ${ }^{43}$ Most of the other Wexford commissioners were necessarily far more active in collecting depositions, a task carried out across the period from 26 December 1653 to 4 April 1654. Eighty-two of the surviving depositions were compiled within the first five days, with seven commissioners sharing the workload. A team of three men conducted many of the investigations at this early stage: Harte, Walker and Stoddard. Harte's signature appeared on 201 depositions overall, the last of 
which was taken as early as 16 February. This was four more than the number signed by Walker, the next most active commissioner, although the latter was active into April. Ambrose Andrews and Edward Withers were also prominently involved, acting as examiners for 153 and 146 depositions respectively. ${ }^{44}$ Among the large number of appointees elsewhere in the country, it is possible to single out some whose local knowledge and experience of the rebellion would have equipped them to play an important role in gathering evidence concerning delinquency. Dr Henry Jones, who had been involved in collecting depositions in the 1640 s and again in the early 1650 s, was named to the commission in Dublin. ${ }^{45}$ The Dr Maxwell appointed in Belfast was almost certainly Dr Robert Maxwell, formerly rector of Tynan in Co. Armagh. Following the outbreak of the rebellion, Maxwell had spent some time as a prisoner of the rebels, an experience that he recounted in a lengthy deposition sworn in August 1642. Maxwell's sensational evidence, which included the claim that there was 'above 154000 now wanting of the brittish within the very precinct of Ulster', was among that incorporated into John Temple's influential History of the Irish rebellion, first published in 1646.46 In Connacht, the government seized upon an offer made by Sir Charles Coote 'of proofs, on behalf of the Commonwealth, against most of the persons who have any considerable estates' ${ }^{47}$ Coote had played a leading military role in the west throughout the conflict, with the result that he and his officers were well placed to report on the wartime activities of Catholic landowners in that region. ${ }^{48}$ The availability of men such as Jones, Maxwell and Coote to serve on delinquency commissions would have made what was an enormous task appear somewhat more manageable. 
As was often the case in 1650s Ireland, some of the officials charged with collecting delinquency depositions did not satisfy the expectations of their superiors in Dublin. In December 1654 the government noted that no returns had been made from the four precincts of Athlone, Athy, Dublin and Kerry, and it urged the relevant commissioners to pursue the 'speedy perfecting' of their work. ${ }^{49}$ Numerous depositions had indeed been collected in Athlone, but the documents had evidently not yet been sent to Dublin. ${ }^{50}$ As late as February 1655, the government issued a demand for the sending in of depositions from ten counties located across four of the fifteen precincts. ${ }^{51}$ In Connacht, the commissioners' 'remissness and absence from that service' was noted as a major problem, one that the government sought to address by reproaching Coote and by dispatching a payment of fifty pounds to encourage greater diligence. ${ }^{52}$

The slow pace of progress in Connacht seems to have been at least partly due to the likelihood that some Old Protestants, including Coote, took the opportunity to create an official record of their own sufferings and service during the war. In the precinct of Athlone, for example, depositions were collected concerning the 'delinquency' of Coote and one of his officers, Captain Richard St George. The deposition of Hugh McGanly concerning St George was in effect a recital of the latter's seemingly unblemished loyalty; after the burning of his house by the rebels, St George had taken up arms and thereafter remained always loyal to the cause of the English parliament. The production of such evidence may have helped to reinforce Coote's position in the face of suspicions that he and his men were crypto-royalists. These proceedings also enabled Coote to put some further distance between his men and those local Protestants who had unambiguously supported the royalist cause, such as the Croftons of Mote. ${ }^{53}$ 
These apparent efforts in Connacht to advertise loyalty in adversity and to settle old scores among the Old Protestants would inevitably have proved a distraction from the main business of investigating Catholic landowners. In some other precincts, however, it appears that the delinquency commissioners proved both diligent and enthusiastic. In Limerick, for example, the commissioners had by April 1656 shifted their attention from landowners to apprentices, servants, craftsmen and 'the younger sons of proprietors' in the city of Limerick. ${ }^{54}$

III

The delinquency commissioners appointed in 1653 were instructed to examine upon oath 'such witnesses as can be produced against those proprietors that have land within your precinct'. In order to direct their work, the Dublin government issued a set of thirteen interrogatories, or questions, which witnesses were expected to answer. 55 The examination of witnesses under interrogatories was an established practice long available to parties to cases in the court of chancery. A similar method had also been used in collecting depositions from Protestant refugees in the early 1640s; much of the evidence compiled at that time is comprised of responses to eight questions relating to topics that included the value of property lost, the names of those responsible, and acts of murder. ${ }^{56}$ It is worth reproducing the interrogatories in full, because they provide an important and ready insight into the work of the delinquency commissions, as well as into the contents of the resulting depositions.

1. Whether the supposed Delinquents did live in Ireland in the first year of the Rebellion, or since and where; whether in the enemy's quarters and how long, 
and whether they might not have removed thence into the Parliament's quarters within the said year, and whether any English in and near the said places did not then remove and come into the English quarters.

2. Whether the said persons did during the first year of the Rebellion remove out of any garrison into places remote from them near to the enemy's quarters.

3. Whether in the first year of the Rebellion, and before 10th November 1642, they did in anything contribute to the enemy's force, or whether they were of any county militia there raised.

4. Whether they have abetted the Rebellion or robberies then or since committed, or did aid in the summoning of any English garrison.

5. Whether they have attended public meetings of the rebels, to promote the Rebellion in the first year of the Rebellion, or since, when and where.

6. Whether they have been of, or have joined in the election of such as have been of the Supreme Council, or of any Provincial, or County Council during the first year or since, and where and when.

7. Whether they have subscribed any oath of association or otherwise against the Parliament or the Commonwealth of England and their forces.

8. Whether they did treat with foreign states, or brought in arms, merchandise etc. for the rebels.

9. What offices or places of trust, civil or martial, were occupied by them in the first year or since, where and when.

10. Whether they had father, sons, brothers or servants in the first year of the Rebellion or since, and whether they repaired to, or held correspondence with them, or did receive assistance.

11. Whether any English have lived on their lands and what has become of them. 
12. Whether in the first year of the Rebellion they did take any goods or arms of the English living amongst them as aforesaid, by what warrant, and whether they received any pillage during the said first year of the Rebellion.

13. Whether they knew of any murders or robberies committed on the English in the said first year of the Rebellion, and whether they did shelter [the perpetrators of] such. ${ }^{57}$

Some of the contents of these interrogatories echoed the definition of delinquency approved by the English parliament in 1643 to guide sequestration proceedings against royalists. ${ }^{58}$ Yet it is clear that much of the agenda set out in 1653 was specific to the Irish context. Moreover, while the commissioners' instructions did not restrict them to investigating Catholic landowners, it is apparent from the interrogatories that the authorities were concerned primarily with collecting information on that group so as to drive forward the ambitious schemes of confiscation and transplantation. The sustained focus on the first year of the rebellion was also informed by the government's transplantation policy, under which all persons involved in the conflict prior to November 1642 were liable to be removed to Connacht. This was the period during which most atrocities against Protestants were believed to have occurred. ${ }^{59}$

The text of the delinquency depositions that have survived usually commence with a statement of the name, address, occupation and age of the deponent, together with the details of the person whose conduct was being inquired into. Deponents were also required to state the 'cause of their knowledge'. The recording of responses to thirteen interrogatories was no small task. Much of the time, however, the individuals who supplied evidence did not 
answer every question. Issues such as involvement in diplomatic negotiations were obviously not relevant in most cases. In Wexford, one particular method used by the commissioners helped substantially to reduce their workload. The first deposition taken concerning a suspected delinquent was often lengthy and carefully structured around the interrogatories. Subsequent depositions relating to the same persons were, however, frequently recorded as condensed narrative summaries, often on the back of the same pages that contained the initial more extensive evidence. ${ }^{60}$ This approach made it easier to collate multiple depositions concerning the same suspect.

Two developments early in 1654 helped to simplify the work of the delinquency commissioners. First, it appears that the unearthing of the records of the Catholic Confederation, and in particular the extensive rolls containing the names of those who had subscribed the Confederate oath of association, allowed the interrogatory concerning the taking of oaths to be taken less seriously. The response most frequently made to that interrogatory had not in any case proved very revealing. Deponents had usually voiced the presumption that the person under investigation had taken the oath of association because it could not have been possible for them to avoid doing so. ${ }^{61}$ Greater detail was, however, sometimes provided. For example, David Devereux of Knockhowlin, Co. Wexford, was confident that his neighbour Thomas Devereux had subscribed the oath of association because he had heard that 'the masse doores' in Thomas's parish had been shut and 'noe man permitted to departe till he \& they respectively had taken the said oath'.62

The second development that helped to simplify the work of the delinquency commissioners was a government instruction issued in February 
1654 with a view to 'the more quick dispatch of that service'. ${ }^{63}$ This instruction was prompted by a suggestion from the delinquency commissioners at Athlone; they had quickly tired of the task of seeking answers to a large number of interrogatories. The government duly instructed the commissioners to concentrate their efforts on determining if a suspect could be linked to murders, or if he had been involved in in the first year of the rebellion. Where evidence of either offence was found, the commissioners were excused from the obligation to gather further information concerning less serious misdemeanours. ${ }^{64}$ Many of the surviving delinquency depositions from Co. Cork emerged from such expedited proceedings, consisting of little more that a brief statement that the suspect 'was in actual armes' in the first year. ${ }^{65}$ Further proceedings could be referred to the High Court of Justice, or put back until after the delinquent concerned had relocated to Connacht. In Wexford, however, the commissioners continued to conduct extensive inquiries even after the government had suggested a scaling back of their operations. This has helped to ensure that the delinquency depositions for Co. Wexford constitute a remarkably rich source for the history of the 1640 s and early 1650 s in that county.

IV

The 513 surviving delinquency depositions from Co. Wexford are comprised of evidence provided by 112 individuals. ${ }^{66}$ It ought to be worthwhile to sketch a profile of this group of deponents, sixty-four of whom were able to sign their names. Their ages are given in 104 cases, ranging from 24 up to 75 years. 


\begin{tabular}{|l|l|}
\hline Age Range & No. of Deponents \\
\hline $20-29$ & 12 \\
$30-39$ & 33 \\
$40-49$ & 25 \\
$50-59$ & 20 \\
$60-69$ & 13 \\
$70-79$ & 1 \\
\hline
\end{tabular}

The eldest deponent, a yeoman called Phillip O Cassey, had formerly been a servant to William Browne of Mulrankan. Browne was one of the two men tasked by Nicholas Stafford with raising regiments in the county in 1641 . Towards the end of that year, O Cassey accompanied his master, now styled Colonel Browne, to the siege of Duncannon Fort. Before the delinquency commissioners in February 1654, he recounted seeing James Duffe of New Ross in arms and commanding a company of men during the siege.$^{67} \mathrm{O}$ Cassey was one of eight deponents to give evidence against Duffe, who was involved in a number of military actions in the first year of the rebellion. ${ }^{68}$

Data relating to social status or occupation, meanwhile, is available for 94 of the deponents, with gentlemen making up by far the largest category.

\begin{tabular}{|l|l|}
\hline Occupation & No. of Deponents \\
\hline Esquire & 5 \\
Yeoman & 20 \\
Gent & 41 \\
Knight & 1 \\
Merchant & 6 \\
Tradesman & 7 \\
Wife/Widow & 3 \\
Other & 11 \\
\hline
\end{tabular}

In the course of their evidence relating to suspected delinquents, deponents often revealed a good deal of information about themselves as well. For example, a number of those described as yeomen or farmers had served as soldiers in the 1640s. It is therefore useful in some cases to look beyond the primary occupational descriptors that occur in the opening line of most of the 
delinquency depositions. Robert Browne offers useful example. Referred to as either a farmer or yeoman in the twenty-four depositions sworn by him, he had been a soldier in Colonel Browne's company in 1641-2 and present at the sieges of Duncannon and Tintern in that period. ${ }^{69}$

One of the striking features of the data relating to status and occupation in the Wexford delinquency depositions is the contrast with the depositions for that county dating from the $1640 \mathrm{~s} \cdot{ }^{70}$ In common with the rest of the country, the earlier Wexford deponents had included a sizeable cohort of despoiled Protestant ministers. Given that the Church of Ireland had been swept away after 1647 , the absence of these voices in 1653-4 is unsurprising. Women also featured less prominently in the 1650 s, with only three of them providing evidence to the delinquency commissioners. ${ }^{71}$ All three were apparently Protestant, indicating that the Catholic women who quite obviously made up a large part of the population in the county played no part in the delinquency proceedings. Most prominent was Margaret Hitchins, a sixty-year old widow who provided eight depositions. At the outbreak of the rebellion she was a servant to Sir Walsingham Cooke in the north of the county at Tomduff. ${ }^{72}$ In a deposition sworn by him in January 1642, Cooke claimed that he had settled 200 Protestant families on his lands. ${ }^{73}$ While Cooke and others fled, Hitchins remained in the area after Thomas Masterson had seized possession of the estate. In April 1642 she went out with her neighbours to meet the Masterson's corpse when it was returned for burial after his death at the Battle of Kilrush. ${ }^{74}$

Hitchins appears to have been one of a number of Protestants who remained in the county throughout the conflict. Most of these individuals were victims of robbery at an early stage of the rebellion, after which they evidently 
adopted a variety of survival strategies. Most unfortunate was Hitchin's neighbour William Oulton, a gardener, who was on a refugee ship bound for Milford when it sank near Arklow. After swimming ashore he was imprisoned in the castle there and fell ill, 'becoming a criple'. Oulton subsequently befriended Hugh Cavanagh, a Catholic whose brother in law Alexander Redmond had taken possession of his cattle. When Cavanagh petitioned the Confederate government for the safe return of Oulton's cattle, Redmond had them slaughtered. ${ }^{75}$ The Protestant merchant John Bond remained in residence in Wexford town, although he was 'Comitted into the Dungeon' along with his father and his brother during Cromwell's siege and storm in 1649.76 The experiences of several other Protestant deponents who remained in Co. Wexford can also be reconstructed; the factors that enabled them to remain included friendly Catholic neighbours and strong front doors. ${ }^{77}$

Amidst the turmoil of the 1640 s, one of the surest survival strategies was conversion to Catholicism. ${ }^{78}$ There are several references among the delinquency depositions to Protestant apostates, at least two of whom are identifiable as deponents in 1654. William Penrust had been among a party of Protestants robbed of their goods in December 1641 while en route from New Ross to the garrison at Enniscorthy. ${ }^{79}$ Ralph Waddington's wife and children were lost at sea as they fled from the rebellion. After his conversion, he sought compensation before the Confederate courts at Kilkenny from Shane Oge Morchoe, who had seized a number of his cattle in 1641. Controversy ensued, however, when Waddington approached the Wexford county council in a doomed attempt to recover a bible robbed from his wife before her departure. He consequently 
found himself 'vnder a cloud and out of fauour', while the bible remained in the hands of Fr Nicholas French. ${ }^{80}$

In his subsequent role as Catholic bishop of Ferns, French also concerned himself with those local Protestants such as Francis Talbot who, unlike Waddington, refused to convert. When Talbot died in 1646, French ordered that he be buried at night 'without priest, cross, book or prayer'. ${ }^{81}$ In 1654 one deponent recounted how Talbot had declined early opportunities to flee because he was confident that the rebellion would not spread to Wexford.82 The harsh reality of the unfolding crisis would certainly have become clear to him by February 1642 when Thomas Fitzharris seized possession of an estate at Staplestown that he had previously mortgaged to Talbot. More than a decade later, one of Talbot's former tenants reported Fitzharris's declaration that 'the said Talbot was a protestant \& shold nowe haue nothing to doe with his Land'. ${ }^{83}$ The Wexford delinquency depositions provide evidence of a number of other cases where Catholics likewise resumed possession of lands that had earlier passed to Protestants. ${ }^{84}$

The evidence provided by Margaret Hitchins and other Protestants complements the details contained in the depositions sworn more than a decade earlier by those Protestants who fled to Dublin for safety. While this longer-term local Protestant perspective is certainly valuable, the factor that most clearly distinguishes the Wexford delinquency depositions from those compiled in the 1640s is the preponderance of Catholic deponents. Many Catholics provided detailed eyewitness evidence relating to the wartime actions of neighbours, relatives, their former masters or landlords, and their one-time comrades in arms. It is these multiple and rich 'embedded' perspectives that lend particular 
value to the documents under discussion. They shed significant light on the roles played by a large number of individuals both in military matters and in Confederate administration in the county. Moreover, because the delinquency commissioners appear to have dispassionately recorded the evidence presented to them, it is possible to recover something of the deponents' individual personalities, as well as their by no means uniform opinions about the events of the previous decade.

The latter aspect is well illustrated in the depositions of William Stafford of Taghmon. While described as a gentleman in 1654, Stafford had been servant to Nicholas Dormer at Camolin in 1641. In the aftermath of the rebellion, he acted as clerk to the county council that provided local government in Wexford. He was then elected to the Confederate general assembly that met at Waterford in 1643 and later acted as a commissioner for army revenues. In addition, he was employed as clerk to the quarter sessions and assizes in Wexford between 1645 and 1649, being present when Cromwell's army stormed the town in the latter year. ${ }^{85}$ This substantial involvement meant that Stafford was well equipped to provide a large amount of evidence to the Cromwellians. He duly proved the most prolific deponent, providing sixty statements in total. One of the more notable elements in his evidence was his responses to the first interrogatory, which focused on the issue of whether suspected delinquents could have spurned the rebellion by removing themselves into English quarters. Whereas many depositions formulaically record that the person under investigation 'did not remove as he might have done', Stafford again and again protested that any Catholic who relocated would have risked the loss of his property. In relation to his former master, he drew additional attention to his fragile health, noting that 
Dormer's removal would have entailed 'hazarding the said Nicholas his life being a weake man'.86 Stafford refrained, however, from defending Catholics who had relocated into the county after the rebellion had begun. Referring to Philip Hore, who moved from his home in Co. Dublin to an estate that he owned in Wexford, Stafford expressed the view that 'the said Hore might haue saflye remoued himeselfe and famely into Dubline'. ${ }^{87}$ Nicholas Stafford, the aforementioned former governor, was also a prolific deponent. He was, however, notably less inclined than William Stafford to justify individual Catholics' decisions to remain on their estates in 1641. For example, he stated that William Esmond of Johnstown might 'without danger' have moved to Duncannon Fort, where his Protestant uncle Lord Esmond was governor. ${ }^{88}$

In most of the depositions sworn by Catholics in Co. Wexford, the rebellion and the subsequent erection of Catholic military and administrative structures was portrayed as defensive action in support of the 'Irish cause'. 89 There was some condemnation, however, of certain individuals who plundered Protestant neighbours on their own initiative, without warrant from the county council or other authorities. The perhaps strongest Catholic critique was contained in the fourteen depositions sworn by Richard Shorthall of Enniscorthy. In 1641 he had been an agent with some responsibility for Lord Esmond's estate, working particularly closely with the latter's Catholic wife. In 1654 Shorthall lambasted various Catholics who had 'arrogantly \& Rebelliously' plundered Protestants' goods in $1641 .^{90}$ He supplied, for example, details of Eneas Cavanagh's 'Rebellyous \& villanous actions' in robbing and expelling Abel Ram and his family 'in a most tyrannous, \& barbarous manner'. Shorthall also recounted the 'high and insolent Nature' of warrants issued for various purposes 
by Sir Morgan Cavanagh, one of the leaders of the rebellion in the region. ${ }^{91}$ Another local notable criticised by Shorthall was Pierce Butler of Clough. He recalled how Butler was 'generally called Catholicque Peirce signifying his zeale \& affection' for Rinnucini, the papal nuncio to Ireland. While stressing Butler's deep commitment to the Catholic war effort, Shorthall also revealed that 'one George Jabelin, an english taylor' had continued as a servant and tenant to Butler throughout the conflict. ${ }^{92}$

Shorthall and his fellow deponents provided evidence relating to the wartime behaviour of some 276 suspected delinquents. The commissioners focused most of their investigations on individuals, although there are several depositions that deal in a more general fashion with groups of inhabitants of the town of New Ross. In many cases, the responses offered to the tenth interrogatory covered suspects' sons and brothers, thus shedding some light too on wider circles of family involvement. ${ }^{93}$ Careful analysis of this data would allow considerable further insights into the structures and personal networks that supported Catholic military, political and administrative endeavours in Co. Wexford in the 1640s, as well as into responses to the arrival of Cromwell's army in 1649. In addition, it would enable better understanding of the local roles played by those men who were involved too at the national level in the politics of the Catholic Confederation. For example, the contents of the Wexford delinquency depositions shows that at least eighteen of the individuals investigated in 1653-4 had sat in one or more Confederate general assemblies in the 1640s. Three of these men were among the group of at least eighteen suspected delinquents who in turn acted as deponents, thus providing the 
Cromwellian regime with even more nuanced multi-directional perspectives on a broad range of the incidents and individuals that made up the 1641 rebellion. ${ }^{94}$

V

Unsurprisingly, Sadleir's officers and their fellow commissioners did not like what they saw. In the mid-1650s officers and officials in the south east of the country emerged as the most trenchant supporters of universal Catholic transplantation to Connacht, a position exemplified in a petition that they drew up early in 1655. Its authors argued that there were 'few or none that are thirty years of age but have had a hand in the murdering or robbing of the English'. They also warned that newcomers living alongside Catholics risked the fate of those Tudor-era settlers who had 'become one with those Irish as well in affinity as idolatry'. ${ }^{95}$ In Co. Wexford, families such as the Mastersons and the Colcloughs provided good examples of this phenomenon, providing between them eight of the individuals investigated in 1654 . Historians have quite reasonably argued that Cromwellian attitudes towards 1641 were heavily influenced by the portrayals of the rebellion contained in pamphlets and other publications. ${ }^{96}$ Beyond print culture, the delinquency commissions may also have played an important role in informing Cromwellian understandings of 1641 . The officers and officials who engaged in this work essentially underwent a crash course in the local minutiae of the rebellion, allowing them to relate the spectre of the 'bloody' Irish rebel to hundreds of local names and faces. It was in this context that the authors of the 1655 petition suggested that leniency towards the Irish would provoke divine retribution and, citing various scriptural precedents, they asked ' shall we join in affinity with the people of these abominations?' ${ }^{97}$ Such 
fervour was, however, soon abated as, with tenants and labourers in short supply, Cromwellian officers adapted to their new roles as Irish landowners. ${ }^{98}$

Also in 1655, proceedings got under way in the Athlone-based court established by the government to hear and determine the claims and entitlements of Catholic transplanters. It would issue decrees to more than 1,800 claimants over the following two years. ${ }^{99}$ Almost all of the detailed source material relating to this court's proceedings was destroyed in $1711 .{ }^{100}$ As a result, it is not possible to reconstruct exactly the manner in which it made use of various types of evidence. The judges had access to the records of the Catholic Confederation and to the depositions collected in the 1640s, all rendered more usable through the diligent compilation of alphabetical indexes. ${ }^{101}$ It also seems certain that the court, in deliberating upon 'all and singular the crimes, offences and misdemeanours of any the persons so making such claim to any lands', must have made extensive use of the delinquency depositions that had been recently compiled precisely along those lines. Indeed towards the end of 1655 the judges complained that the absence of such depositions from some counties was obstructing the conclusion of 'sundry causes depending before them'.102 It appears then that the delinquency commissions, despite being almost entirely overlooked by historians, played a crucial role in facilitating the transplantation to Connacht. The evidence of the surviving delinquency depositions can be used not only to reconstruct aspects of the 1641 rebellion but also to fill a notable gap in scholarly understanding of the information-gathering exercises that helped to facilitate implementation of the Cromwellian land settlement.

Once proceedings had concluded at Athlone, all of the depositions and other relevant papers were lodged in a room above the council chamber in 
Dublin known as the Discrimination Office. ${ }^{103}$ After 1660 these materials assumed central importance in the context of the scramble for land under Restoration settlement. In an eight-month period in 1663 a court of claims issued around 700 decrees of innocence, allowing the mostly Catholic claimants to recover possession of their confiscated estates. Many other former proprietors failed to obtained decrees due to the short duration of the court's sitting. ${ }^{104}$ The criteria for obtaining a decree of innocence were quite strict and, as with the earlier delinquency commissions, involvement in 1641 was treated as a crucial determinant of an individual's fate. When many Catholics nonetheless succeeded in proving their innocence in the opening months of 1663, this provoked a strong Protestant reaction. ${ }^{105}$

Significantly, many of the records originally housed in the Discrimination Office had been withdrawn, making them unavailable for use as evidence by Protestants endeavouring to thwart Catholic claimants. ${ }^{106}$ On 10 February 1663 the uniformly Protestant Irish House of Commons accordingly went on the offensive, passing a series of resolutions that called for a change of approach. ${ }^{107}$ A few days later the speaker, Sir Audley Mervyn, presented the resolutions in a bombastic speech before the lord lieutenant, the duke of Ormond. Warning that 'the Alarm (that Hannibal is at the Gates) is hot throughout the Protestant Plantations', Mervyn presented the Commons' demand that 'all Examinations and Depositions whatsoever, taken ... as well during his late Majesties Reign, or in the time of the Usurped Authority ... as also the Books of Kilkenny, be taken for good evidence'. Recognising that a proposal to use depositions collected by the Cromwellians was bound to prove controversial, Mervyn insisted that 'if out of 
Acts of usurped Powers, his Majesty settles the Peace of his Kingdoms, it is but a part of Royal Chymistry, out of poysonous Minerals to extract a Cordial'.108

Although Ormond accused Mervyn of scaremongering, this campaign eventually had the desired effect. A notice dated 23 March that appeared in the newsbook Mercurius Hibernicus revealed that there were 'many original letters, Examinations, Orders, Petitions, Muster-Rolls and other material papers lately brought into the Discrimination Office'.109 On 24 March a delinquency deposition was introduced in evidence before the court of claims for the first time. ${ }^{110}$ Overall, delinquency depositions from nine different counties would be employed as evidence in at least thirty-one cases. ${ }^{111}$ Yet despite Mervyn's insistence on the potency of 'Royal Chymistry', the records of the court's proceedings indicate a continued and understandable hesitation about the use of Cromwellian records. They tended to be used as a last resort when little or no alternative evidence could be found to incriminate a claimant. ${ }^{112}$ At the same time, the controversy that these documents helped to generate proved central to the wider efforts of the 'Protestant interest' to preserve its landed gains from the 1650s while at the same time distancing itself in all other respects from the deeds of the 'late usurper'.113

One further context in which the delinquency depositions appear to have been employed in the early 1660s was in proving the king's title to lands that the crown wanted to bestow on favourites. This activity was distinct from the work of the court of claims, and fragmentary surviving sources make it difficult to reconstruct in any great detail the attendant legal proceedings. When Charles II wished to reward a courtier or some other individual with an Irish estate, the relevant provincial escheator had to provide for an inquisition to be held in the 
county where the lands were located. ${ }^{114}$ In Dublin and some other counties where large numbers of Catholics had been indicted and outlawed for rebellion in the early 1640 s, the proceedings instituted in the 1660 s could effectively take the form of belated inquisitions on attainder. ${ }^{115}$ The latter was the final step in the traditional legal process whereby the lands of outlaws were resumed into the hands of the crown; it would again feature prominently in Ireland in the 1690s. ${ }^{116}$ The fact that the collapse of authority in 1641 had prevented the state from convicting outlaws in many counties had potential to pose problems when it came to making new royal grants in those same counties in the 1660 s.

In relation to Co. Wexford, the testimony of Protestant refugees who fled to Dublin had been used to indict more than 800 local Catholics in 1642-3.117 The subsequent steps in the outlawry process were, however, not completed. ${ }^{118}$ This shortcoming was brought into focus two decades later when the king elected to bestow an estate worth $£ 500$ per annum on the courtier Sir Daniel O'Neill.119 Suitable lands were identified in Co. Wexford out of parts of various estates and a commission was issued that included the names of twenty-one former Catholic proprietors. ${ }^{120}$ The necessary inquisition was held in Wexford on 7 May 1663. In both content and phrasing, the limited surviving evidence from this inquisition strongly indicates that the information contained in the delinquency depositions helped to inform the proceedings. ${ }^{121}$ As in the court of claims, the authorities apparently proved willing to resort to Cromwellian records so as to plug gaps in the available evidentiary base. Delinquency depositions survive relating to almost all of the men mentioned in the 1663 inquisition. Moreover, the range of offences highlighted in 1663, such as living in rebel quarters, bearing arms at Duncannon, holding various local offices and giving relief to sons who were in 
rebellion, were precisely the matters described at length in the delinquency depositions. ${ }^{122}$ One specific incident detailed in several depositions, the administering of the Confederate oath of association by Fr Thomas Hampton to a group assembled in the church at Baldenstown in 1642, was used as evidence against John Wadding. Just as in 1654, Wadding was cited in 1663 as the priest's assistant, the man who 'did hold the book'.123 The similar inquisitions held in a number of other counties in 1663-4, and the forms of evidence used therein, are just some of many the aspects of this period that bear further investigation.

VI

Even post-digitisation, the 1641 depositions remain in many respects challenging for scholars to use. By reconstructing the context within which the Cromwellian delinquency commissions operated, this article has aspired to enable better understanding of the origins and purpose of a substantial part of that controversial archive. It has also sought to assess the contemporary significance of the delinquency depositions by exploring their impact both on attitudes towards 1641 and on a variety of major legal processes relating to landownership in mid-seventeenth century Ireland. The material relating to Co. Wexford discussed above offers only a further flavour of the vast and intricate data preserved in the delinquency depositions for that county. They constitute an unrivalled source for research into the individuals, the actions and the attitudes that made up the 1641 rebellion in that region. The delinquency proceedings and the resulting depositions are also further evidence of the remarkable administrative energy displayed by sections of the Cromwellian regime as it went about enforcing peace, transporting priests, shipping soldiers, 
mapping land and transplanting Catholics. They were the product of an attempt to anatomise the Irish rebellion so as to enable the purging from three provinces of persons tainted by their involvement in that episode, and their orderly resettlement in the fourth. Karl Bottigheimer's choice of poetic simile to characterise 1650s Ireland, 'like a patient etherized upon a table', appears ever more apt. ${ }^{124}$

${ }^{1}$ John Gibney, The shadow of a year the 1641 rebellion in Irish history and memory (Madison, 2013); Aidan Clarke, “The "1641 massacres”, in Jane Ohlmeyer and Michéal Ó Siochrú (eds), Ireland: 1641. Contexts and reactions (Manchester, 2013), pp 37-49. The 1641 depositions (T.C.D. MSS 809-41) are available at http://www.1641.tcd.ie. Publication by the Irish Manuscripts Commission is ongoing.

2 Jennifer Wells, 'English law, Irish trials and the Cromwellian quest for legitimacy and power in the 1650s', Past \& Present (forthcoming, 2015). ${ }^{3}$ On the background to the land settlement, see John Cunningham, Conquest and land in Ireland: the transplantation to Connacht, 1641-1680 (Woodbridge, 2011), pp 11-47.

${ }^{4}$ Charles Firth and Robert Rait (eds), Acts and ordinances of the interregnum (3 vols, London, 1911), i, 106-17; H. J. Habakkuk, 'Landowners and the civil war' in Ec.H.R., second series, xviii (1965), pp 130-51.

${ }^{5}$ Cunningham, Conquest and land, pp 17-30.

6 Ibid. pp 39-44.

${ }^{7}$ Cunningham, Conquest and land, pp 48-73. 
${ }^{8}$ For an analysis of this organisation, see Micheál Ó Siochrú, Confederate Ireland, 1642-1649: a constitutional and political analysis (Dublin, 1999).

${ }^{9}$ Robert Dunlop (ed.), Ireland under the Commonwealth (2 vols, Manchester, 1913), ii, 378-9.

10 '1641 depositions' (http://1641.tcd.ie/index.php) (1 Oct. 2014). The figure of 1,260 was arrived at following analysis of those depositions that postdate the establishment of the delinquency commissions.

${ }^{11}$ H.M.C., Eighth report (London, 1881), appendix, section 3, pp 572b-576b;

Aidan Clarke, 'The 1641 depositions', in Peter Fox (ed.), Treasures of the Library, Trinity College Dublin (Dublin, 1986), pp 116-18; 'Main Categories'

(1641.tcd.ie/using-categories.php.) (accessed 1 Oct. 2014). This remains the case in Clarke, 'The "1641 massacres"', p. 43, although he does draw attention to the divergent content of the relevant Wexford depositions.

12 Padraig Lenihan, Confederate Catholics at war 1642-49 (Cork, 2001), pp. 38-44; Elaine Murphy, 'Siege of Duncannon Fort in 1641 and 1642', in Eamon Darcy, Annaleigh Margey and Elaine Murphy (eds), The 1641 depositions and the Irish rebellion (London, 2012), pp 143-54; Jason McHugh, '"For our owne defence": Catholic insurrection in Wexford, 1641-2', in Brian Mac Cuarta (ed.), Reshaping Ireland, 1550-1700: colonization and its consequences (Dublin, 2011), pp 214-40. ${ }^{13}$ Mary Hickson (ed.), Ireland in the seventeenth century: or, the Irish massacres of 1641-2 (2 vols, London, 1884), ii, 148; Samuel Gardiner, 'The transplantation to Connaught' in E.H.R., xiv (1899), pp 717, 723; Moritz Bonn, Die Englische Kolonisation in Irland (2 vols, Stuttgart and Berlin, 1906), ii, 38-9; Cunningham, Conquest and land, p. 82. 
14 This will complement existing work on Wexford in, for example, Murphy, 'Siege of Duncannon Fort', pp 143-54, and McHugh, ' Catholic insurrection in Wexford', pp 214-40.

15 Dunlop (ed.), Ireland under the Commonwealth, ii, 378-9.

16 John Prendergast, The Cromwellian settlement of Ireland (2nd ed., London, 1870), pp 157-8.

17 The two counties are Wexford (T.C.D. MSS 818-19) and Cork (T.C.D. MSS 8268).

18 The ten counties for which delinquency depositions can be either directly or indirectly identified are are Cork, Dublin, Galway, Kerry, Kilkenny, Limerick, Roscommon, Tipperary, Waterford and Wexford.

${ }^{19}$ Deputy Keeper of the Public Records in Ireland (henceforth D.K.P.R.I.), Fourteenth report (London, 1882), pp 38-9.

${ }^{20}$ Geraldine Tallon (ed.), Court of claims: submissions and evidence, 1663 (I.M.C., Dublin, 2006), p. 554.

${ }^{21}$ D.K.P.R.I., Fourteenth report, pp 22-52.

${ }^{22}$ Idem, Twentieth report (Dublin, 1888), pp 25-6; John Gilbert, A history of Dublin (3 vols, Dublin, 1854-9) ii, 150.

${ }^{23}$ William O’Sullivan, 'John Madden's manuscripts' in Vincent Kinane and Anne Walshe (eds), A history of the Trinity College Library, Dublin (Dublin, 2000), pp 104-10.

${ }^{24}$ John Gilbert (ed.), A Jacobite narrative of the war in Ireland, 1688-1691 (Dublin, 1892), p. 250.

25 O’Sullivan, 'John Madden's manuscripts', pp 104-10. 
${ }^{26}$ See, from Co. Tipperary, the Examination of John Walsh, 14 Feb. 1654 (T.C.D., MS 830, ff 249r-50v). The Co. Limerick Examination of George Saunders, 31 Aug. 1656, appears to relate to delinquency proceedings in Limerick City around that time (T.C.D., MS 829, ff 431r-2v).

27 Wexford depositions (T.C.D. MSS 818-19).

${ }^{28}$ Clare and Limerick depositions (T.C.D., MS 829, ff 110r-13v, 387r-430v).

${ }^{29}$ O’Sullivan, 'John Madden's manuscripts', p. 109.

${ }^{30}$ Most of these are in three of volumes of the Cork depositions (T.C.D. MSS 8268).

31 List of delinquency commissioners, Dec. 1653 (N.L.I. MS 11,959, pp 349-51).

32 Dunlop (ed.), Ireland under the Commonwealth, ii, 380.

${ }^{33}$ See, for example, the delinquency depositions for Cork in T.C.D., MS 827.

${ }^{34}$ List of delinquency commissioners, Dec. 1653 (N.L.I. MS 11,959, pp 349-51);

Wexford depositions (T.C.D., MSS 818-19).

35 Charles Firth, The regimental history of Cromwell's army (2 vols, Oxford, 1940), ii, 582-3.

36 Ibid., i, 348 and ii, 418, 582-3; Abstract of an army muster, 28 Sept. 1657 (B.L., Add. MS (Petty) 72,877, ff 72r-74v); Prendergast, Cromwellian settlement, pp 158, 309-10; Aidan Clarke, Prelude to Restoration in Ireland: the end of the Commonwealth, 1659-1660 (Cambridge, 1999), pp 209-11; References to petitions and other Cromwellian documents (St Peter's College Wexford, Hore MS 60, pp 319, 348, 353-4, 872-4: microfilm, N.L.I., p4024); Liam Gaul, Johnstown Castle: a history (Dublin, 2014), chap. 2. 
${ }^{37}$ H. E. Nott (ed.), The deposition books of Bristol, 1650-1654 (Bristol Record Society, xiii, Bristol, 1948), 77, 100; Examinations of Richard Neale, 27 and 28 Feb. 1652 (T.C.D. MS 819, ff 36r-v, 282r-3v, and 286r-v).

38 Robert Simington (ed.), The Civil Survey, A.D. 1654-1656, ix: County of Wexford (I.M.C., Dublin, 1953), p. xiv; William Hardinge, 'On circumstances attending the outbreak of the civil war in Ireland', Trans. of the Royal Irish Academy, xxiv (1873), p. 410.

${ }^{39}$ Joseph Swan, 'The justices of the peace for the county of Wexford', Jn. of the Royal Soc. Antiq. of Ire., 5th ser., iv (1894), p. 67.

40 'Sadleir (Sopwell Hall)',

(http://landedestates.nuigalway.ie/LandedEstates/jsp/estateshow.jsp?id=3279) (accessed 13 Dec. 2014).

${ }^{41}$ Examination of William Stafford, 18 Jan. 1654 (T.C.D., MS 819, ff 177r-8v). 42 Ibid.; Examinations of David Devereux and Richard Shorthall, 16 Jan. 1654 (ibid., ff 179r-81v).

${ }^{43}$ Examinations of Morris Neale and Henry Roach, 27 Feb. 1654 (ibid., ff 35r-6v). 44 Wexford Depositions (T.C.D., MSS 818-19, passim).

45 Aidan Clarke, 'The commission for the despoiled subject, 1641-7', in Brian Mac Cuarta (ed.), Reshaping Ireland, 1550-1700: colonization and its consequences (Dublin, 2011), p. 242; John Cunningham, '1641 and the shaping of Cromwellian Ireland', in Darcy, Margey and Murphy (eds), The 1641 depositions and the Irish rebellion, pp 155-68.

46 Deposition of Robert Maxwell, 22 Aug. 1642 (T.C.D., MS 809, ff 5r-12v); Clarke, 'The “1641 massacres"”, pp 41-2. 
47 Dunlop (ed.), Ireland under the Commonwealth, ii, 400.

48 Patrick Little, 'Coote, Charles, first earl of Mountrath (c.1610-1661)', ODNB.

${ }^{49}$ Dunlop (ed.), Ireland under the Commonwealth, ii, 471.

50 Extracts from delinquency proceedings in the precinct of Athlone, 1653-4

(King's Inns Library, Prendergast MS 1, pp 686-712).

51 Dunlop (ed.), Ireland under the Commonwealth, ii, 567.

52 Ibid., 525, 558; Edward MacLysaght, 'Commonwealth state accounts, 1650-

1656' in Anal. Hib., no. 15 (1944), p. 276.

53 Transcripts of Examinations of Hugh McGanly and Capt. Richard St George, Jan. 1654, (King’s Inns Library, Prendergast MS 1, pp 707-9, 711-12); D.K.P.R.I., Fourteenth report, pp 38-9.

${ }^{54}$ Dunlop (ed.), Ireland under the Commonwealth, ii, 589-90. For a Limerick deposition from 1656, see Examination of George Saunders, 31 Aug. 1656 (T.C.D. MS 829, ff 431r-2v).

55 Dunlop (ed.), Ireland under the Commonwealth, ii, 378-9.

56 Clarke, 'The 1641 depositions', p. 113.

57 Dunlop (ed.), Ireland under the Commonwealth, ii, 378-9.

58 Firth and Rait (eds), Acts and ordinances, i, 106-17.

${ }^{59}$ Cunningham, Conquest and land, pp 40-4.

${ }^{60}$ See, for example, the series of Wexford delinquency depositions in T.C.D., MS 818, ff 224r-329v.

61 See, for example, ibid., ff 264r-v and 279r-v. In Co. Wexford, responses to the seventh interrogatory were less frequently recorded after 18 Jan. 1654 . See T.C.D., MSS 818-19. 
62 Examination of David Devereux, 16 Jan. 1654 (T.C.D., MS 818, f. 275r-v).

63 Dunlop (ed.), Ireland under the Commonwealth, ii, 401-2.

${ }^{64}$ Ibid.; The Athlone delinquency commissioners to the commissioners of parliament, 13 Dec. 1653 (King's Inns Library, Prendergast MS 1, p. 689).

65 See T.C.D., MS 827, passim. In the precinct of Cork, receipt of the government's instruction to expedite proceedings was noted at ibid., f. 42r.

66 Wexford depositions (T.C.D., MSS 818-19). The summary statistics presented in the following paragraphs are based on analysis of these manuscripts.

${ }^{67}$ Examination of Phillip 0 Cassey 7 Feb. 1654 (T.C.D., MS 819, f. 37v).

68 See, for example, Examination of John Connick, 9 Feb. 1654 (ibid., f. 38r-v).

${ }^{69}$ See, for example, Examinations of Robert Browne, 8 Feb. 1654 (T.C.D., MS 818, ff $184 \mathrm{r}$ and $293 \mathrm{v})$.

70 These are preserved in ibid., ff 24r-192v.

${ }^{71}$ Dorothy Billings, Margaret Hitchins and Ursula Row.

72 Examination of Margaret Hitchins, 14 Mar. 1654 (T.C.D., MS 818, ff 297v-8r.).

${ }^{73}$ Deposition of Sir Walsingham Cooke, 5 Jan. 1642 (ibid., ff 82r-3v).

${ }^{74}$ Examination of Margaret Hitchins, 14 Mar. 1654 (T.C.D., MS 819, f. 164v).

75 Examination of William Oulton, 14 Mar. 1654 (ibid, f. 253r-v).

76 Examination of John Bond, 13 Jan. 1654 (ibid., f. 22r-v).

77 See, for example, Examinations of Jonas Rushworth, 16 and 28 Feb. 1654 (ibid., ff $98 \mathrm{r}-9 \mathrm{v}$ and $304 \mathrm{r}-\mathrm{v})$.

${ }^{78}$ For a discussion of issues around conversion, see McHugh, 'Catholic insurrection in Wexford', pp 236-8.

${ }^{79}$ Examination of William Penrust, 28 Feb. 1654 (ibid., f. 41r). 
${ }^{80}$ Examination of Ralph Waddington, 31 Mar. 1654 (ibid., ff 168v-9v);

Examination of William Stafford 4 Jan. 1654 (T.C.D., MS 818, 269r-70v).

${ }^{81}$ H.M.C., The manuscripts of the duke of Portland (London, 1891), p. 403.

82 Examination of William Stafford, 29 Dec. 1653 (T.C.D., MS 819, f. 300r-v).

${ }^{83}$ Examination of Richard Whitty, 6 Jan. 1654 (T.C.D., MS 818, f. 238v).

${ }^{84}$ See, for example, Examination of Ursula Row, 11 Jan. 1654 (T.C.D. MS 819, ff 79r-80v).

85 Examinations of William Stafford, 26, Dec. 1653 and 18 Jan. 1654 (ibid., ff 226r-7v, and MS 818, 202r-3v, 279r).

${ }^{86}$ Examination of William Stafford, 18 Jan. 1654 (T.C.D., MS 818, f. 279r).

87 Examination of William Stafford, 28 Dec. 1653 (T.C.D., MS 819 f. 240r-v).

${ }^{88}$ Examination of Nicholas Stafford, 26 Dec. 1653 (T.C.D., MS 818 ff 204r-205r).

${ }^{89}$ On this point, see McHugh, 'Catholic insurrection in Wexford', pp 214-40.

90 Examination of Richard Shorthall, 2 Mar. 1654 (T.C.D., MS 819, f. 88v).

${ }^{91}$ Examinations of Richard Shorthall, 1 Mar. 1654 (T.C.D., MS 818, ff 317r-v and 320r-v).

92 Examination of Richard Shorthall, 16 Jan. 1654 (T.C.D., MS 818, 312r-13v).

93 Wexford Depositions (T.C.D., MSS 818-19, passim).

${ }^{94}$ Ibid. For general assembly attendance, see Ó Siochrú, Confederate Ireland, pp 251-60.

95 Gardiner, 'The transplantation', pp 723-6.

${ }^{96}$ For a discussion of this point, see Cunningham, '1641 and the shaping of Cromwellian Ireland', pp 155-68.

${ }^{97}$ Gardiner, 'The transplantation', pp 723-6. 
${ }^{98}$ Cunningham, Conquest and land, pp 76-9.

99 Ibid., pp 82-6.

100 On the fire of 1711 , see the contemporary report by Dr Richard Stone printed in Cal. S.P. Ire., 1603-6, p. Ixxxii.

${ }^{101}$ Cunningham, Conquest and land, pp 82-6. For the use at Athlone of depositions from the 1640s, see John Prendergast and Charles Russell (eds), The Carte manuscripts in the Bodleian Library: a report (London, 1871), pp 147-51 and Prendergast, Cromwellian settlement, pp 156-7. For an index to some of the 1641 depositions, see T.C.D., MS 841. For an index to several books of the Catholic Confederation, see National Archives, Kew, SP 63/287/196.

102 Dunlop (ed.), Ireland under the Commonwealth, ii, 469-71, 558.

103 Warrant by the duke of Ormond, for granting to Sir Allan Brodrick the use of certain rooms over the Council Chamber, 11 Sept. 1662 (Bodl., Carte MS 163, f. $21 v)$.

104 Laurence Arnold, The Restoration land settlement in County Dublin, 1660-1688 (Dublin, 1993), pp 37-70.

105 Ibid., p. 71.

106 The various types of evidence used in individual cases can be traced in Tallon (ed.), Court of claims.

107 Arnold, Restoration land settlement, p. 71.

108 Audley Mervyn, The speech of Sir Audley Mervyn, Knight; his majesties prime serjeant at law, and speaker of the house of commons in Ireland (Dublin, 1663), pp $3-4,13,16$.

${ }^{109}$ Mercurius Hibernicus, no. 10, 17-24 Mar. 1663, p. 73. 
110 Tallon (ed.), Court of claims, p. 46.

111 Ibid., passim. See, for example, case nos 147, 188, 245, 458 and 553.

112 Ibid.

113 Cunningham, Conquest and land, pp 119-27.

${ }^{114}$ Sir Daniel O'Neill to Ormond, c. 21 Aug. 1663 (Bodl., Carte MS 159, f. 67v.);

Nicholas Bolton to Ormond, c. 23 Feb. 1664 (ibid., ff 201v-202r).

115 For those outlawed, see Robert Simington and John MacLellan, 'Oireachtas

Library List of outlaws, 1641-1647', Anal. Hib., xxiii (1966), pp 319-67.

116 John Simms, The Williamite confiscation in Ireland, 1690-1703 (London, 1956), pp 30-44.

117 See Kevin Whelan, 'A list of those from County Wexford implicated in the 1641 rebellion', The Past: the Organ of the Uí Chinsealaigh Society, xvii (1990), pp 24-54.

118 D.K.P.R.I., Seventeenth report (Dublin, 1885), pp 13-19.

119 The king to Ormond, 13 Oct. 1662 (Bodl., Carte MS 43, f. 21).

120 Letters patent for Daniel O'Neill, 13 Nov. 1663 (N.A.I., Lodge MS 7, pp 11617).

121 Inquisitionum in officio rotolorum cancellariæ Hiberniæ asservatarum, repertorium (2 vols, London, 1826-9), i, 3-Car. II.

122 Ibid.

${ }^{123}$ Ibid.; On Wadding and this particular episode, see Examinations of Robert Browne, 30 Jan. 1654 (T.C.D., MS 819, ff 59v and 141r-2v).

${ }^{124}$ Karl Bottigheimer, English money and Irish land: the 'adventurers' in the Cromwellian settlement of Ireland (Oxford, 1971), p. 117. 